IJEAL (International Journal of English and Applied Linguistics)

Volume : 1 | Number 3 | December 2021 |E-ISSN : 2787-9482 | DOI: doi.org/ijeal.v1n1.1199

\title{
THE USE OF ENGLISH IN PROMOTING FASHION
}

\author{
Desi Andriani \\ UPI YPTK Padang, Padang, Indonesia
}

Andrianidesi33@gmail.com

Received: 26/11/2021

Accepted: 06/12/2021

Publication: 06/12/2021

\begin{abstract}
This research is conducted to know the use of English in promoting fashion in social media. In social media, many people upgrade their style to sell. They sometimes used English to advertise to attract readers' attention to buy. The research aims to know the use of English in terms of the meaning of language and word order of the English used in promoting fashion. This research is a kind of descriptive research. The researcher took the data from sellers' posts on social media. The data were analyzed based on two variables. They are grammar and word order. The research results showed that the English used to promote fashion is incorrect and does not follow the correct word order and grammar.
\end{abstract}

Keywords-English, Promoting, Fashion

\section{Introduction}

Fashion is something that is not rare for a human being. Fashion, especially clothes, is the prime need for people. Like food and drink, fashion also includes the main requirement of humans. Many people also sell this important thing. In the traditional market, so many people sell fashion. In the supermarket also many fashions are offered. Some people who do not like to shop in the conventional market choose to shop in the supermarket.

Meanwhile, supermarkets and traditional markets are replaced by the online shop today. The reason is because of the pandemic, and it is also cheaper than buying it directly. People can save their time; they only stay at home, see handphones, and order things they want. Then, it will come to the shoppers' house in some days. It can be paid when the items arrive.

Clothing is not unusual anymore for all people today (Ahmad, 2016). All people want to look fashionable, trendy, and shar'i. Like the character of people, they tend to like beauty. Both the beauty of the appearance and the beauty of the environment. In terms of appearance, everyone wants a beautiful appearance, so it is not uncommon for people to allocate funds or money for the fashion or clothing needs they enjoy (Andriani \& Putri, 2021) because it is also a special need and pleasure when wearing fashion that is good and according to taste.

Because of the many fashion/clothing enthusiasts at this time, few manufacturers or companies offer a variety of fashion products that are of public interest. (Yet, 2013) Then various media were used to promote it, such as mass media and social media (Plaisime et al., 2020). Mixed media display advertisements to promote their products to the public (Fahd \& Sugiarto, 2015). And not infrequently, these ads also use English to attract buyers' interest (Astrid, 2011). However, not rarely, the use of English is not quite right (Andriani \& Anggraini, 2020). Then this study examined the English language 
used in the promotion of clothing on social media in terms of the effectiveness of the English language used. English is used to promote fashion (Andriani, 2019). Promotion/advertising are all forms of activities to present and promote ideas, goods, or services non-personally (Yudi Farola Bram, 2005). The criterion used to determine the key factor is whether the information will affect the promotional choices (Heriyanti, 2013).

Advertisement or promotion is not only related to industry and marketing media (Ligia Agnes Pratistia, Lisbeth Mananeke, 2014). Promotion is a part of marketing (Lane, 2016). This is used to communicate to the market. There are some functions of promoting (Iye et al., 2020): giving information, influencing, making sense, satisfying willingness, and an advertisement is a communication tool. Marketing fashion is an effort of a company to promote the product to the market (Sarastuti, 2017).

\section{Research Method}

This research is a descriptive one. Descriptive analysis determines and reports how things are (Sugiyono, 2004). It is told about something that occurs in the field. Further, Gay and Airasian also add two reasons why people use the descriptive method. First, a high percentage of reported research studies are illustrative. Second, the descriptive approach is useful for investigating varieties of problems. Data were taken from posts of the sellers on Instagram. Then, the data were analyzed based on two indicators. They were Word order and grammar.

\section{Results and Discussions}

There are many names of sources in Instagram of sellers that were analyzed. All of them offer their product to the readers. Some of them are in the following explanation.

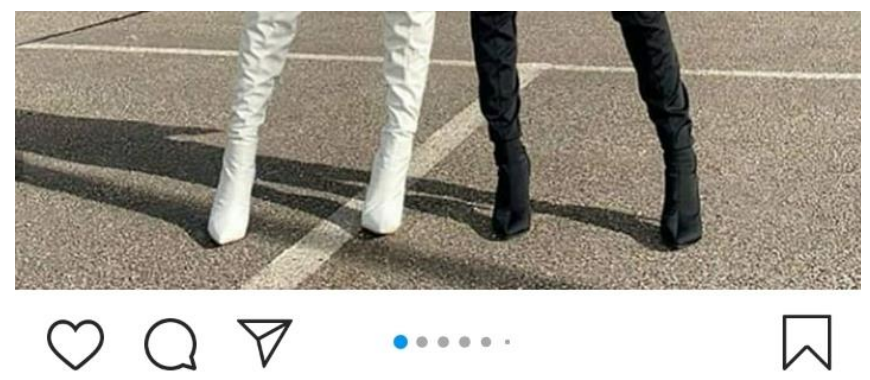

27 suka

girlsfashion_world_1103 Comment one is your favorite...? Like comment follow 5

$24 \mathrm{Mei} \cdot$ Lihat Terjemahan

In this promotion of fashion, the sentence of the seller was imperative. The seller asks $t$ comment which one is the buyer's favorite. The meaning of the sentence is 'beri komen favorite.' But the sentence does not complete. It has blank space. Actually, for a promotion, it should not have freedom. Space can cause readers' misunderstand. Therefore, the seller should state 'comment one is your favorite trouser. Your favorite consists of your possessive adjective; famous is as an adjective. So, to make it a noun phrase, it must be followed by a noun. The noun such as trouser can complete the sentence since the seller promoted trouser. 
IJEAL (International Journal of English and Applied Linguistics)

Volume : 1 | Number 3 | December 2021 | E-ISSN : 2787-9482 | DOI: doi.org/ijeal.v1n1.1199

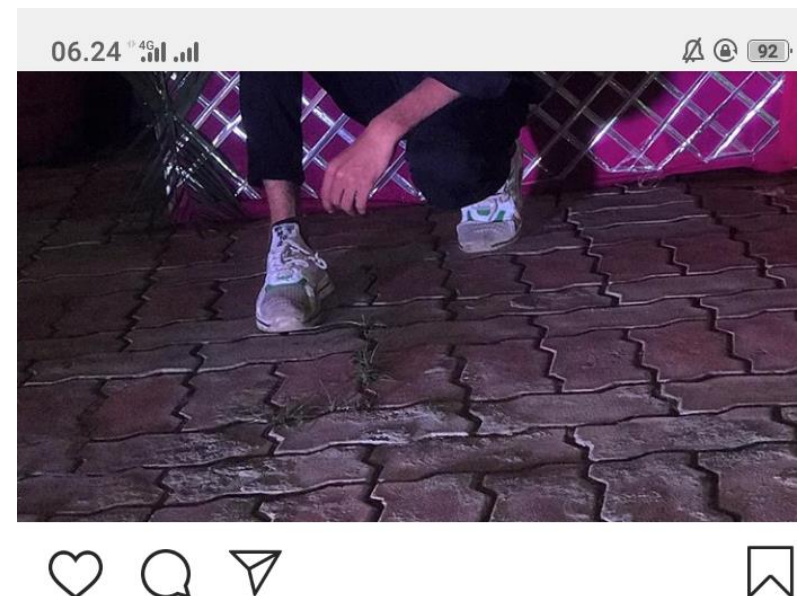

100 suka

mr_attu "You must be the change you wish to see in the world Q $1 . . .$.

The sentence of the promotion in this item is not arranged well. 'you' is as subject, 'must' is as modal, 'be' is as to be, 'the' is as article, change is as a verb. 'You wish' it should be your wish. So, it is a possessive adjective. When it is 'you wish,' it should be two sentences. It means that it is a subordinate clause. Article 'the' is not appropriate since 'change' is a verb. 'Wish' is a noun. So before a noun, it cannot have a subject such as in the sentence 'you wish.' It can be a subject, but it must use conjunction. The correct sentence is 'you must change your wish to see the world.

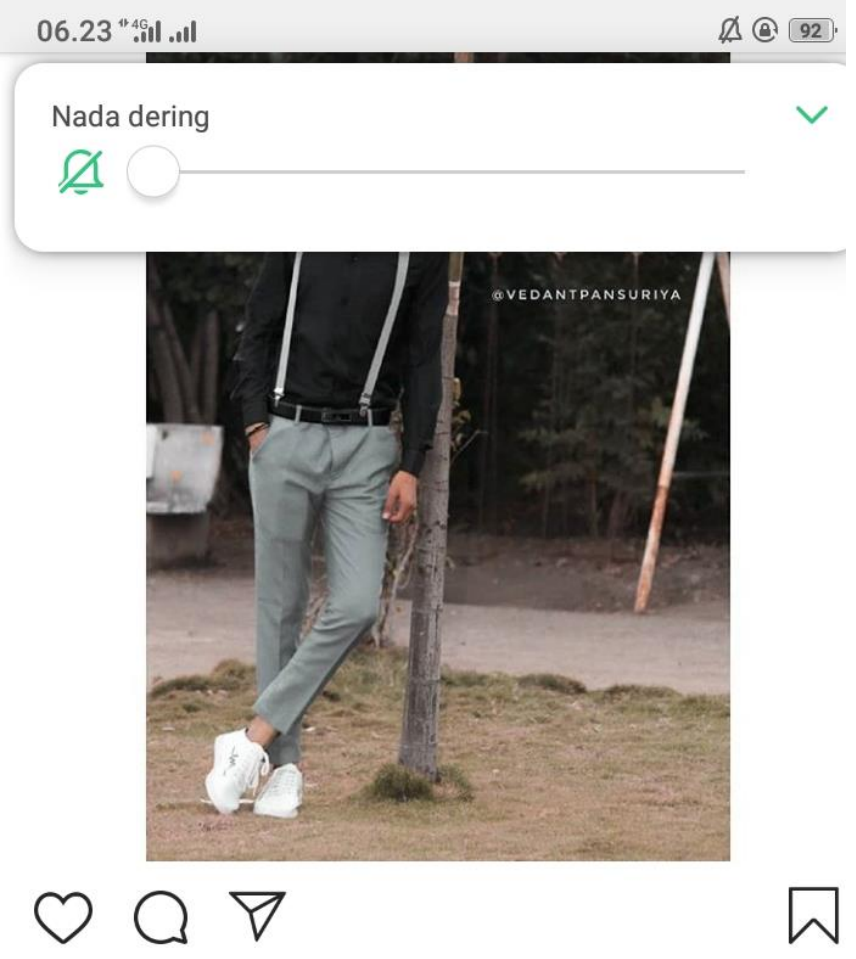

\section{6 suka}

vedantpansuriya You can have anything you want in life if you dress for it...... 
The sentence in the above promotion should be 'you can have anything that you want in your life if you dress for it.' Since 'you want' is also a sentence, it is a compound sentence. It should have a conjunction such as that. So, one clause is the main clause, and another is the subordinate clause.

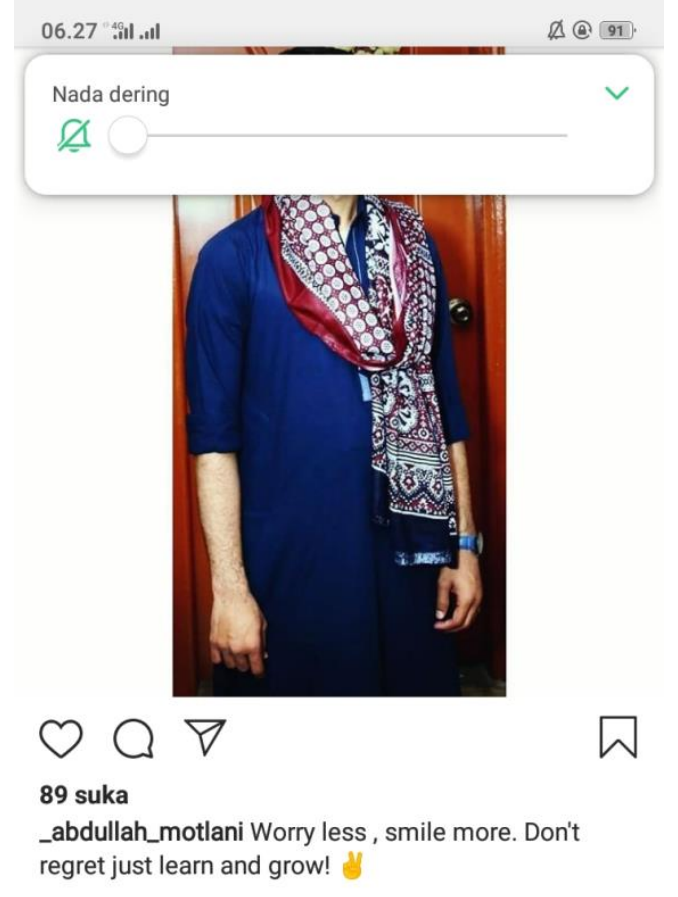

The punctuation in the sentence does not complete. It should have correct punctuation. The sentence should be 'worry less, smile more. Don't regret it; learn and grow. It is a kind of willingness. Willingness to be happy in our life. So, the seller wants everyone to be satisfied. So, besides offering their things, the seller also provides happiness to the readers.

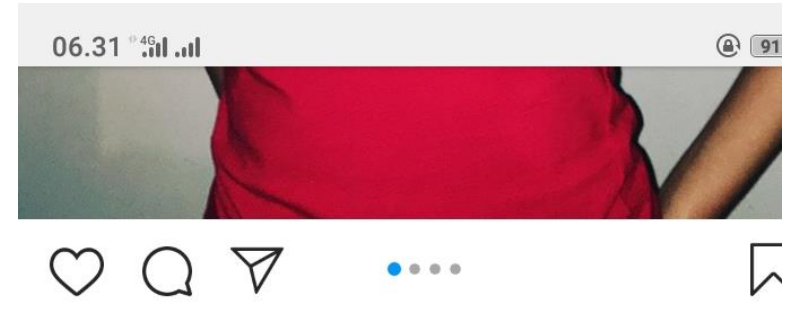

\section{4 suka}

crusty_vente_de_vetements Red Ferrari women's top this top ranges in style $u$ can wear it on any occasion looking FLASH whenever and wherever. ORIGINAL PRICE-\$110. SELLING PRICE- \$50 (negotiable)

In the promotion above, the seller offers a women's top. The seller's punctuation should be corrected. The revised sentence is 'red Ferrari women's top, this top ranges in style, you can wear it on any occasion. You will look fresh whenever and wherever. 


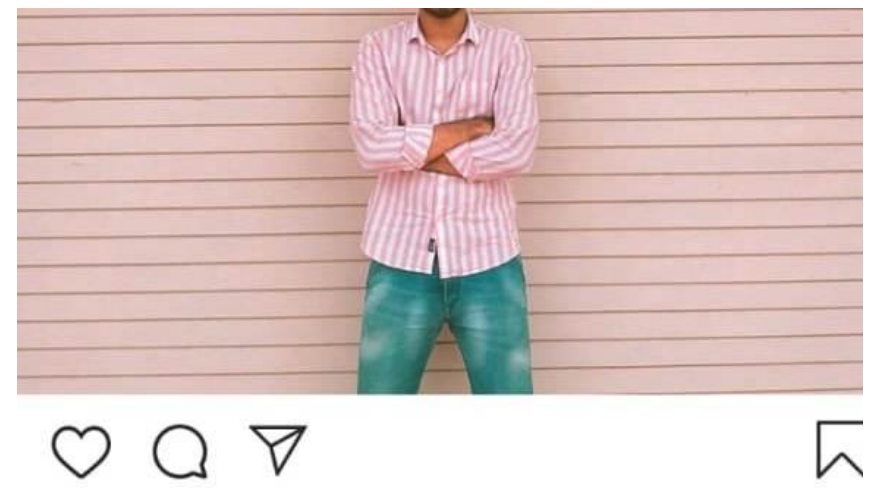

\section{2 suka}

mr_angry_brd__Don't change to fit the fashion.

Change the fashion to fit you. \#fashion \#modeling

The promotion above, the sentence should be revised. Revision is used to make readers easy to understand the text. It should be 'don't change to fit your fashion, change your fashion to fit you.'

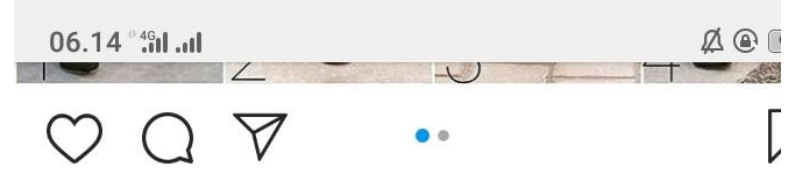

24 suka

girlsfashion_world_1103 1-8 which one is your

favorite...? Follow us for more

(@fashion_world_1103)

(@the_gown_1103

2 Juni - Lihat Terjemahan

In this promotion of fashion, the sentence of the seller was imperative. The seller asks $t$ comment which one is the buyer's favorite. The meaning of the sentence is 'yang mana favorite.' But the sentence does not complete. It has blank space. Actually, for a promotion, it should not have empty space. Blank space can cause readers' misunderstanding. Therefore, the seller should state 'which one is your favorite skirt. Your favorite consists of your possessive adjective; favorite is as an adjective. So, to make it a noun phrase, it must be followed by a noun. The noun such as trouser can complete the sentence since the seller promoted the skirt.

\section{Conclusion}

English used in promoting fashion is not good. The promotion is still wrong in using a noun, using an adjective, using an adjective, subject, verb, object, and word order. English used in promotion should be correct since many people see the sentence of advertising. There are still some sentences of advancement that should be revised to make them understandable. For instance, in making noun phrases, the penalty should have nouns at the end of the noun phrase. 
IJEAL (International Journal of English and Applied Linguistics)

Volume : 1 | Number 3 | December 2021 |E-ISSN : 2787-9482 | DOI: doi.org/ijeal.v1n1.1199

\section{References}

Ahmad, I. bin. (2016). Konsep Pakaian dan Teori Semantik. Seni Pakaian, 29-44. repo.iaintulungagung.ac.id/3229/2/BAB II.pdf\%0A\%0A

Andriani, D. (2019). An Analysis of Reading Texts. ANGLO-SAXON: Jurnal Ilmiah Program Studi Pendidikan Bahasa Inggris, 10(1), 15. https://doi.org/10.33373/anglo.v10i1.1921

Andriani, D., \& Anggraini, D. (2020). An Analysis of Students' Ability in Transating Texts. ELTLectura, 7(2), 154-159. https://doi.org/10.33369/joall.v1i1.3797

Andriani, D., \& Putri, D. M. (2021). An analysis of english used in promoting fashion in social media busana di media sosial. 5, 161-170. https://doi.org/10.22216/kata.v5i1.74

Astrid, A. (2011). Pembelajaran Tata Bahasa Inggris secara Komunikatif dengan penyajian induktif dan pengintegrasian keterampilan berbahasa: studi kasus di kelas Bahasa Inggris I di IAIN Raden Fatah Palembang. Ta'dib: Journal of Islamic Education (Jurnal Pendidikan Islam), XVI(2), 175-208.

Fahd, F., \& Sugiarto, Y. (2015). Analisis Pengaruh Promosi Terhadap Impulse Buying Melalui Emosi Positif. 4(2005), 1-8.

Heriyanti, R. (2013). Bahasa Inggris dalam Iklan Busana Muslimah pada Majalah Aulia. Komunika, 7(2). https://scholar.google.co.id/scholar?q=related:zD5tehbOemUJ:scholar.google.com/\&scioq=Her iyanti,+R.+(2013).+Bahasa+Inggris+dalam+Iklan+Busana+Muslimah+pada+Majalah+Aulia.+ 7(2).\&hl=id\&as_sdt=0,5

Iye, R., Susiati, S., \& Karim, K. (2020). Citra Perempuan dalam Iklan Sabun Shinzui. Sang Pencerah: Jurnal Ilmiah Universitas Muhammadiyah Buton, 6(1), 1-7. https://doi.org/10.35326/pencerah.v6i1.529

Lane, J. (2016). Analisis Elemen Visual Pada Promosi Busana Muslimah Di Instagram ( Studi Kasus Merek Hijab. 89-100.

Ligia Agnes Pratistia, Lisbeth Mananeke, J. S. (2014). Pengaruh Kualitas Produk, Harga, Promosi dan Lokasi terhadap Pembelian Konsumen. EMBA, 2(3), 1737-1749.

Plaisime, M., Robertson-james, C., Mejia, L., Núñez, A., Wolf, J., \& Reels, S. (2020). Social Media and Teens: A Needs Assessment Exploring the Potential Role of Social Media in Promoting Health. https://doi.org/10.1177/2056305119886025

Sarastuti, D. (2017). Sarastuti: Strategi Komunikasi Pemasaran. Jurnal Visi Komunikasi, 16(01), 71-90.

Sugiyono. (2004). Metodologi Penelitian dan Profil Desa. 48-67.

Yet, S. (2013). Analisis efektivitas iklan tv sirup markisa dengan pendekatan epic model pt . Majujaya pohon pinang pada konsumen swalayan macam yaohan merak jingga medan Sian Yet Paham Ginting. Modernisasi, 9(1), 16-32.

Yudi Farola Bram. (2005). Analisis Efektivitas Iklan Sebagai Salah Satu Strategi Pemasaran Perusahaan Percetakan Dan Penerbitan Pt Rambang Dengan Menggunakan Metode Epic Model. Jurnal Manajemen \& Bisnis Sriwijaya, 3(6), 1-23. 